\title{
PERAN PONDOK PESANTREN SEBAGAI LEMBAGA PENDIDIKAN ISLAM DI INDONESIA
}

\author{
Tatang Hidayat ${ }^{1}$, Ahmad Syamsu Rizal ${ }^{2}$, Fahrudin $^{3}$ \\ 1.2.3) Program Studi Pendidikan Agama Islam, \\ Sekolah Pascasarjana, Universitas Pendidikan Indonesia \\ J1. Dr. Setiabudhi No. 299 Bandung 40154 Jawa Barat - Indonesia \\ Email: 1tatanghidayat@upi.edu; 2rizal@upi.edu; 3fahrudin59@upi.edu
}

DOI: $10.29313 /$ tjpi.v7i2.4117

Accepted: May 10th, 2018. Approved: April 9th, 2019. Published: April 9th, 2019

\begin{abstract}
This present study aims at identifying the role of Islamic boarding schools as Islamic educational institutions in Indonesia. This study employed a qualitative approach and literature study method. Based on the results of the study, Islamic boarding schools in fact provided the process of teaching, educating, developing, and spreading the religion of Islam. In relation to the objectives of Islamic boarding schools, it in principle aims to develop Islamic personality, specifically the personality that put more concern on the believing and consciousness of Allah, noble character, piety, usefulness and loyalty to the community, and being a custodian of all bumankind (khadim al-ummah). The role of Islamic boarding schools in Indonesia was not only as educational institutions but also it took a role as a religious institution operated as a basis against any kind of colonialism, as knowledge institutions, research institutions, training institutions, and community development institutions, and cultural bonds.
\end{abstract}

Keywords: Islamic Boarding Schools, Islamic Educational Institutions, Indonesia.

\begin{abstract}
ABSTRAK
Tujuan pembahasan ini untuk mengetahui peran pondok pesantren sebagai lembaga pendidikan Islam di Indonesia. Pembahasan ini menggunakan pendekatan kualitatif dan metode studi literatur. Berdasarkan hasil pembahasan, pondok pesantren merupakan lembaga pendidikan Islam yang memberikan pengajaran, pendidikan, pembinaan dan menyebarkan agama Islam. Tujuan pendidikan pesantren adalab dalam rangka membina kepribadian Islami, yaitu kepribadian yang beriman dan bertakwa kepada Allah Subhānahu Wa Ta'alâ, berakblak mulia, bermanfaat dan berkbidmat kepada masyarakat dengan menjadi pelayan umat (khadim al-ummah). Peran pondok pesantren di Indonesia bukan hanya sebagai lembaga pendidikan tetapi berperan juga sebagai lembaga keagamaan yang menjadi basis perlawanan terhadap segala bentuk penjajahan, lembaga keilmuan, lembaga penelitian, lembaga pelatihan, dan lembaga pengembangan masyarakat sekaligus menjadi simpul budaya.
\end{abstract}

Kata Kunci: Pondok Pesantren, Lembaga Pendidikan Islam, Indonesia. 


\section{PENDAHULUAN}

Ilmu pengetahuan dan teknologi dari masa ke masa akan terus mengalami perkembangan, karena hakekatnya dalam tataran ideal ilmu itu akan terus berkembang. Pendidikan sebagai proses pengembangan diri dalam membina umat manusia merupakan salah satu bidang yang tidak ada habisnya untuk terus dikaji, mengapa dikatakan demikian, karena pendidikan merupakan salah satu bidang yang sangat penting untuk mengembangkan sumber daya manusia (SDM) yang berkualitas.

Pendidikan merupakan bidang yang berupaya mengembangkan potensi SDM supaya berkualitas dalam menentukan peradaban suatu negeri. Oleh karena itu, kualitas pendidikan di suatu negeri akan mempengaruhi terbentuknya peradaban negeri tersebut (Hidayat, Rizal, \& Fahrudin, 2018). Untuk mewujudkan pendidikan yang berkualitas, pemerintah di negeri ini telah merumuskan tujuan pendidikan yang ingin dicapainya. Dalam Undang-Undang No 20 tahun 2003 tentang sistem pendidikan nasional disana tercantum bahwa tujuan pendidikan nasional ialah Mengembangkan potensi peserta didik agar menjadi manusia yang beriman dan bertakwa kepada Tuhan Yang Maha Esa, berakhlak mulia, sehat, berilmu, cakap, kreatif, mandiri dna menjadi warga negara yang demokratis serta bertanggung jawab.

Berdasarkan tujuan pendidikan nasional, seharusnya output dari penyelenggaraan pendidikan yang ada mestinya selaras dengan tujuan pendidikan nasional yang tercantum dalam UU No. 20 tahun 2003. Namun ternyata kemajuan ilmu pengetahuan dan teknologi jika tidak dibarengi dengan kualitas pendidikan yang memadai, akan menyebabkan kualitas SDM bangsa Indonesia mengalami krisis dari segala bidang. Salah satu bukti nyata yang sedang dialami saat ini adalah meningkatnya berbagai tindakan kriminal yang dilakukan oleh generasi muda bangsa Indonesia seolah menjadi rahasia umum ditengahtengah masyarakat.

Masih maraknya konsumsi minuman keras dikalangan remaja merupakan salah satu problematika yang terjadi di negeri ini. Kapolres Purworejo AKBP Satrio Wibowo melalui Kasat Reskrim AKP Kholid Mawardi melaporkan dalam sindonews.com (5/11/2016) bahwa Adi Kurniawan tewas diduga setelah menenggak minuman keras (miras) oplosan. Satu lagi korban bernama Erlangga Saputra (15) juga meninggal setelah beberapa jam dirawat di IGD RSUD Tjitrowardojo Purworejo.

Di sisi lain, problematika narkoba pun tidak kalah bahayanya yang harus kita sikapi bersama. Kepala BNN Kota Kendari, Murniati dalam detik.com (14/9/2017) melaporkan bahwa kota Kendari telah masuk dalam kategori darurat narkoba. Hal ini setelah adanya kasus 30 remaja dari pelajar tingkat SD, SMP, SMA hingga pegawai mengkonsumsi obat terlarang yang diduga narkoba. Akibatnya 25 orang dilarikan ke rumah sakit dan 1 lainnya tewas.

Bahkan yang tidak kalah mengkhawatirkan, tingkat hubungan seksual di luar nikah ternyata jumlahnya lebih banyak dibandingkan kasus pernikahan dini. Psikolog Forensik Reza Indragiri Amriel dalam jpnn.com (17/4/2018) melaporkan bahwa remaja yang melakukan hubungan seksual di luar nikah jumlahnya lebih banyak dibandingkan kasus pernikahan dini. Oleh karena itu, harusnya dipahami sebagai masalah yang lebih serius.

Tidak sampai disitu, tawuran di kalangan remaja seolah menjadi tradisi yang tidak berkesudahan dan belum ditemukan solusi untuk menyelesaikannya. Bempah (2018) melaporkan dalam kompas.com (4/6/2018) belasan remaja diamankan petugas lantaran terlibat tawuran dengan sekelompok remaja lain di Jalan Pajajaran Kota Bogor, Senin (4/6/2018) dini hari. Bahkan petugas mengamankan sejumlah 
senjata tajam yang digunakan untuk melukai lawan-lawannya.

Timbulnya peningkatan kriminalitas di kalangan remaja bukanlah masalah yang dianggap biasa, karena setiap tahun angka kriminalitas remaja meningkat dan menunjukkan perkembangan yang mengkhawatirkan (Jaafar et al., 2012). Berdasarkan problematika di atas, timbullah kesenjangan antara tujuan pendidikan dengan realita di lapangan. Tentunya problematika yang ada dipengaruhi oleh beberapa penyebab, salah satunya sistem pendidikan materialisme yang diterapkan di negeri ini seolah melahirkan para peserta didik yang kesuksesannya hanya diukur dari segi materi (Syahidin, 2009: 6). Di sisi lain, pendidikan agama Islam (PAI) yang diajarkan di lembaga formal seolah hanya formalitas belaka dan sekedar menggugurkan akademik semata (Effendi, 2002: 210). Buktinya mata pelajaran PAI diajarkan mulai tingkat sekolah dasar hingga perguruan tinggi, namun hasilnya dirasa belum optimal dalam menanamkan nilainilai Islam bagi kehidupan peserta didik.

Berdasarkan uraian diatas, perlu adanya usaha dalam menyelesaikan problematika tersebut, jika tidak akan menghambat dalam proses pendidikan khususnya di lembaga pendidikan formal. Dalam hal ini perlu ada solusi alternatif dalam menyelesaikan problematika tersebut, salah satunya disinilah mesti hadir lembaga pendidikan lain yang dapat membina kepribadian peserta didiknya. Dalam hal ini, pondok pesantren kiranya mampu untuk hadir dan bersaing dalam membina generasi muda bangsa Indonesia supaya bisa lebih baik.

Pesantren merupakan lembaga pendidikan Islam yang sudah ada eksistensinya bahkan sebelum republik ini berdiri (Ridhwan, Nurdin, \& Samad, 2018). Pesantren merupakan sistem institusi pendidikan Islam tertua di Indonesia. Ia lahir dari suatu kearifan lokal nusantara yang telah bertahan secara eksistensial selama berabad-abad. Meskipun demikian, terpaan perkembangan zaman telah menuntut pesantren untuk melakukan perubahan-perubahan (Rizal, 2011).

Kemajuan ilmu pengetahuan dan teknologi yang dibarengi dengan arus globalisasi menuntut pondok pesantren untuk melakukan perubahan-perubahan, jika tidak demikian, pondok pesantren sebagai lembaga pendidikan yang sudah lama berdiri di negeri ini bisa saja kalah saing dengan banyaknya lembaga pendidikan modern yang didirikan. Namun fenomena akhir-akhir ini, In'ami (2011) mengamati bahwa apresiasi masyarakat terhadap pesantren saat ini cukup tinggi, dan kesadaran untuk mengantarkan anakanak ke lembaga pendidikan pesantren mulai tumbuh di tengah persaingan lembaga pendidikan yang memberikan fasilitas dan pelayanan yang lebih, dan tentunya dengan biaya yang tinggi.

Keberadaan pesantren menjadi data tarik dalam segala aspeknya. Baik kiainya maupun sistem pendidikannya. Itulah yang menjadikan pesantren dan apapun yang dimilikinya sebagai kearifan lokal dan kekayaan intelektual dari nusantara (Abubakar, 2018). Pesantren di era globalisasi ini tampaknya perlu dibaca sebagai kekayaan intelektual nusantara yang mampu memberikan kontribusi terhadap lahirnya khazanah intelektual muslim yang berakhlak mulia serta bertanggung jawab terhadap dirinya maupun masyarakat di sekelillingnya (Haryanto, 2017). Oleh karena itu, sangat penting kiranya untuk diadakan sebuah pembahasan sejauh mana peran pondok pesantren sebagai lembaga pendidikan Islam di Indonesia.

\section{METODOLOGI PENELITIAN}

Penelitian ini menggunakan pendekatan kualitatif dan metode kajian pustaka. Teknik pengambilan data yang dilakukan peneliti yakni mengumpulkan data dari berbagai sumber pustaka baik dari buku, jurnal, hasil seminar dan diskusi 
dengan para ahli yang relevan dengan tema penelitian. Setelah data terkumpul, peneliti melakukan analisis data dengan teknik interpretasi data dan peneliti memberikan penjelasan secukupnya ditinjau dari teori yang relevan dengan permasalahan yang dihadapi.

\section{HASIL PENELITIAN DAN PEMBAHASAN}

\section{Pondok Pesantren Sebagai Lembaga Pendidikan Islam di Indonesia}

Nashir (2010: 80) mencatat bahwa pondok pesantren ialah lembaga keagamaan, yang memberikan pengajaran, pendidikan serta mengembangkan dan menyebarkan ilmu agama Islam. Adapun Engku \& Zubaidah (2014: 171-175) melaporkan bahwa kata pesantren sering digunakan dalam bahasa sehari-hari dengan tambahan kata "pondok" menjadi "pondok pesantren". Ditinjau dari segi bahasa, kata pondok dengan kata pesantren tidak ada perbedaan yang mendasar di antara keduanya, karena kata pondok adalah berasal dari bahasa Arab funduq yang artinya hotel dan pesantren. Dalam pemahaman masyarakat Indonesia dapat diartikan sebagai tempat berlangsungya suatu pendidikan agama Islam yang telah melembaga sejak zaman dahulu. Jadi, pada hakikatnya pondok pesantren merupakan lembaga pendidikan Agama Islam.

Adapun dari segi metode pengajaran, Dhofier (1994: 28-29) mencatat bahwa metode utama sistem pengajaran di lingkungan pesantren ialah sistem bandongan atau sistem weton. Dalam sistem ini sekelompok murid mendengarkan seorang guru yang membaca, menerjemahkan, menerangkan dan seringkali mengulas buku-buku Islam dalam bahasa Arab. Setiap murid memperhatikan bukunya sendiri dan membuat catatan-catatan (baik arti maupun keterangan) tentang kata-kata atau buah pikiran yang sulit. Dalam pesantren kadangkadang diberikan juga sistem sorogan tetapi hanya diberikan kepada santri-santri baru yang masih memerlukan bimbingan individual.

Berdasarkan uraian di atas, dapat dipahami bahwa pondok pesantren ditinjau dari segi bahasa, kata pondok berasal dari bahasa Arab funduq yang artinya hotel. Dalam perspektif masyarakat Indonesia diartikan sebagai tempat berlangsungya suatu pendidikan Agama Islam yang telah melembaga sejak zaman dahulu. Jadi, pada hakikatnya pondok pesantren merupakan lembaga pendidikan Islam yang memberikan pengajaran, pendidikan dan menyebarkan agama Islam. Metode utama sistem pengajarannya adalah sistem bandongan / weton dan sorogan.

\section{Unsur-Unsur Pondok Pesantren Sebagai Lembaga Pendidikan Islam di Indonesia}

Pada umumnya, unsur-unsur pondok pesantren terdiri dari kiai, santri, masjid, kitab kuning dan asrama. Alhamuddin (2005) menyimpulkan jika pondok pesantren tidak memiliki salah satu dari yang disebutkan diatas, maka tidak dapat dikatakan sebagai pondok pesantren.

\section{Kiai}

Dhofier (1994: 55) kiai merupakan unsur yang paling esensial dari suatu pesantren dan kiai seringkali sebagai pendiri pesantren. Maka sudah sewajarnya bahwa pertumbuhan suatu pesantren semata-mata bergantung kepada kemampuan pribadi kiainya. Adapun Engku \& Zubaidah (2014: 119-120) mencatat bahwa kiai merupakan tokoh sentral dalam pesantren yang memberikan pengajaran. Oleh karena itu, kiai merupakan salah satu unsur yang paling dominan dalam kehidupan pesantren. Kemasyahuran, perkembangan dan kelangsungan kehidupan suatu pesantren banyak bergantung pada keahlian dan kedalaman ilmu, kharismatik dan wibawa, serta keterampilan kiai yang bersangkutan 
dalam mengelola pesantren. Dalam konteks ini, pribadi kiai sangat menentukan, sebab ia adalah tokoh sentral dalam pesantren. Yahya (2006: 228) menyimpulkan dalam sistem pendidikan pesantren berhasil atau tidaknya suatu pendidikan dipengaruhi oleh individu pengajar dan pelajar. Pengajar dalam hal ini adalah kiai.

Dalam tradisi pesantren salafi, kiai sebagai pengasuh pondok ditempatkan sebagai sentral (panutan), sehingga menyebabkan pondok pesantren dituntut untuk memenuhi seluruh kebutuhan pondok tersebut (Sudarsih, 2010). Sementara itu dalam tradisi pesantren Dhofier (1994: 79) menemukan bahwa sejak Islam masuk di Jawa, para kiai selalu terjalin oleh intellectual chains (rantai intelektual) yang tidak terputus. Ini menandakan antara satu pesantren dengan pesantren lain, baik dalam satu kurun zaman maupun dari satu generasi ke generasi berikutnya, terjalin hubungan intelektual yang mapan hingga perkembangan dan perubahan yang terjadi dalam lingkungan pesantren sebenarnya. Keabsahan (authenticity) ilmunya dan jaminan yang ia miliki sebagai seorang yang diakui sebagai murid kiai terkenal dapat ia buktikan melalui mata rantai transmisi yang biasanya ia tulis dengan rapi dan dapat dibenarkan oleh kiai-kiai lain yang masyhur yang seangkatan dengan dirinya. Dalam tradisi pesantren, rantai transmisi ini disebut sanad.

Santri

Santri adalah seorang anak atau seorang yang menuntut ilmu pada sebuah pondok pesantren atau sebutan para siswa yang belajar mendalami ilmu agama di pondok pesantren (Setiawan, 2012). Santri merupakan unsur pokok dari suatu pesantren, yang biasanya terdiri dari dua kelompok, yaitu: Pertama, santri mukim, yaitu santri yang berasal dari daerah yang jauh dan menetap di pondok pesantren. Kedua, santri kalong, yaitu santri-santri yang berasal dan daerah-daerah sekitar pesantren dan tidak menetap di pesantren, tetapi mereka pulang pergi antara rumahnya dan pesantren (Fauziyah, 2014).

Dalam dunia pesantren, hubungan guru dan murid bukan hanya hubungan menyampaikan ilmu, tetapi ada kedekatan emosional yang terbentuk antara guru dan murid. Rizal (2012) menyimpulkan bahwa kedekatan emosional antara kiai dan santri akan terbentuk, yang pada gilirannya akan terbangun proses identifikasi. Santri secara inisiatif belajar tentang nilai-nilai kehidupan melalui proses penilaian kepada orang yang dikaguminya. Oleh karena itu, kiai sebagai sosok yang dikaguminya akan menjadi teladan bagi para santrinya.

\section{Masjid}

Masjid merupakan elemen yang tidak terpisahkan dengan pesantren, Irham (2015) melaporkan bahwa masjid merupakan manifestasi universalisme dari sistem pendidikan pesantren. Engku \& Zubaidah (2014: 118) memastikan bahwa masjid merupakan unsur pokok kedua dari pesantren, disamping berfungsi sebagai tempat melakukan șalat berjama'ah setiap waktu, masjid juga berfungsi sebagai tempat belajar-mengajar. Pada sebagian pesantren, masjid juga berfungsi sebagai tempat i'tikaf dan melaksanakan latihan-latihan, sulük dan zikir, maupun amalan-amalan lainnya dalam kehidupan tarekat dan sufi.

\section{Kitab Kitab Islam Klasik}

Suryadi (2012) berbicara pendidikan Islam dalam tataran keilmuan tidak dapat dipisahkan dari kajian tentang buku-buku pendidikan yang berbahasa Arab. Ajaran Islam yang bersumber dari Alquran dan hadis yang dikodifikasi dengan bahasa Arab, begitupun dengan buku-buku pendidikan Islam yang banyak ditulis dengan bahasa Arab baik buku klasik maupun modern. Tegasnya, secara sederhana jika kita akan mengkaji tentang aspek-aspek pengetahuan 
dalam Islam, peranan buku-buku bahasa Arab tidak dapat diabaikan.

Senada dengan pendapat di atas, Sanusi (2013: 62) mencatat bahwa ciri khas lain dari pondok pesantren adalah pembelajaran dengan menggunakan kitabkitab tertentu yang biasa disebut sebagai kitab kuning. Kitab ini menjadi rujukan para santri, biasanya kitab ini tidak memakai tanda baca (syakal). Kiai membacakan redaksi dalam kitab tersebut, santri mendengarkan dan menuliskan kembali pemaparan Kiai mengenai kitab yang dikajinya, baik dari segi i'rab, syakal alkalimah dan makna redaksi.

\section{Asrama}

Dhofier (1994: 45-47) pondok bagi para santri merupakan ciri khas tradisi pesantren yang membedakannya dengan sistem pendidikan tradisional di masjidmasjid yang berkembang di kebanyakan wilayah Islam di negara-negara lain. Ada tiga alasan utama kenapa pesantren harus menyediakan asrama bagi para santri. Pertama, kemasyhuran seorang kiai dan kedalaman pengetahuannya tentang Islam menarik santri-santri dari jauh. Untuk dapat menggali ilmu dari kiai tersebut secara teratur dan dalam waktu yang lama, para santri tersebut harus meninggalkan kampung halamannya dan menetap di dekat kediaman Kiai. Kedua, hampir semua pesantren berada di desa-desa dimana tidak tersedia perumahan (akomodasi) yang cukup untuk dapat menampung santrisantri. Ketiga, ada sikap timbal balik antara kiai dan santri, di mana para santri menganggap Kiainya seolah-olah sebagai bapaknya sendiri, sedangkan kiai menganggap para santri sebagai titipan Tuhan yang harus senantiasa dilindungi. Sikap timbal balik ini menimbulkan keakraban dan kebutuhan untuk saling berdekatan terus-menerus.

Engku \& Zubaidah (2014: 117-118) mencatat bahwa adanya pondok pesantren tempat tinggal bersama antara kiai dengan para santrinya, dan bekerja sama untuk memenuhi kebutuhan hidup sehari-hari, merupakan pembeda dengan lembaga pendidikan yang berlangsung di masjid atau langgar. Pesantren juga menampung santrisantri yang berasal dari daerah yang jauh untuk bermukim.

Adanya asrama di pondok pesantren menjadi ciri khas dalam tradisi pesantren, sistem asrama akan membentuk santri menjadi orang yang mandiri sebagaimana dijelaskan Sanusi (2012) jika dibandingkan pendidikan formal, pondok pesantren mampu membentuk santri untuk hidup mandiri. Sistem asrama pada pondok pesantren dan karakteristik kehidupan di dalamnya mendorong santri untuk memenuhi dan menjalankan tugas kehidupan sehari-hari dengan mandiri. Di samping dididik untuk mandiri, sistem asrama telah membentuk santri menjadi pribadi yang ta'at dan peduli terhadap sesama sebagaimana dijelaskan Hasyimi (1988: 177-179) seorang muslim yang ta'at pada-Nya, akan bersifat peduli, baik dalam masalah jual beli atau hal lainnya, terpuji akhlaknya, dan selalu berusaha untuk meringankan kesulitan orang lain.

\section{Klasifikasi Pondok Pesantren Sebagai Lembaga Pendidikan Islam di Indonesia}

Dhofier (1994: 41) menyimpulkan secara garis besar, pesantren pada dewasa ini dapat dikelompokkan menjadi 2 kelompok besar, yaitu : Pertama, pesantren salafi yakni pesantren yang masih mempertahankan pengajaran kitab-kitab Islam klasik sebagai inti pendidikan di pesantren. Adapun sistem madrasah diterapkan untuk memudahkan sistem sorogan yang dipakai dalam lembagalembaga pengajian bentuk lama, tanpa mengenalkan pengajaran pengetahuan umum. Kedua, pesantren khalafi yakni pesantren yang telah memasukkan pelajaran-pelajaran umum dalam madrasahmadrasah yang dikembangkannya, atau 
membuka tipe sekolah-sekolah umum dalam lingkungan pesantren.

Banyaknya variasi pesantren yang ada di Indonesia merupakan sesuatu yang unik dalam dunia pendidikan, Rahardjo dkk (1974: 24-25) menemukan dari hasil analisa dapat diperoleh variabel-variabel struktural seperti bentuk kepemimpinan, organisasi pengurus, dewan kiai atau dewan guru, susunan rencana pelajaran, kelompokkelompok santri, bagian-bagian fungsional yang khusus, dan seterusnya, yang apabila dibandingkan antara satu pesantren dengan pesantren lainnya, dari satu daerah ke daerah lainnya atau dari satu aliran ke aliran lainnya, maka akan kita peroleh tipologi dan variasi dunia pesantren.

\section{Tujuan Pendidikan Pesantren}

Tujuan pendidikan di pesantren adalah pada pengalaman terhadap ilmu yang telah diperoleh yang disebut dengan ilmu bermanfaat (ilm nāji). Ini menjadi keunggulan tersendiri pendidikan pesantren, yakni menggabungkan kecerdasan intelektual, emosional dan spiritual yang muaranya dapat membina karakter seseorang (Tamin AR, 2015). Adapun Engku \& Zubaidah (2014: 177-180) mencatat pada dasarnya fungsi utama pesantren adalah sebagai lembaga pendidikan yang bertujuan mencetak muslim agar memiliki dan menguasai ilmuilmu agama secara mendalam serta menghayati dan mengamalkannya dengan ikhlas semata-mata ditujukan untuk pengabdiannya kepada Allah. Pola pendidikan yang diselenggarakan pesantren beragam. Namun demikian, fungsi yang diembannya sama yakni mendidik dan mengajarkan ilmu-ilmu agama Islam sebagai upaya mewujudkan manusia yang Tafaqquh Fiddin.

Untuk mewujudkan tujuan pendidikan pesantren tersebut, maka diperlukan sebuah program pendidikan pesantren yang lebih progresif namun memiliki hubungan antara tujuan dan fungsi pesantren tersebut, sebagaimana dipahami warga pesantren selama ini (Djumransjah, 2001). Dari uraian di atas, dapat disimpulkan bahwa tujuan pendidikan pesantren adalah dalam rangka membina kepribadian Islami, yaitu kepribadian yang beriman dan bertakwa kepada Allah Subhānahu $W a$ Ta'àlâ, berakhlak mulia, bermanfaat dan berkhidmat kepada masyarakat dengan menjadi pelayan umat (khadim al-ummah) sebagaimana kepribadian Rasulullah Sallâ Allah 'Alaibi Wa Sallam dalam menyebarkan agama Islam.

\section{Peran Pondok Pesantren Dalam Dunia Pendidikan di Indonesia}

Tuanaya dkk (2007: 145) mengamati bahwa di masa penjajah, pesantren telah memainkan peran penting sebagai conter culture bagi sistem pendidikan modern yang diperkenalkan penjajah Belanda. Ketika sistem pendidikan modern ini diteruskan penyelenggaraanya oleh bangsa Indonesia sesudah merdeka, dan kemudian menjadi salah satu pilar yang menyangga proses modernisasi yang berfungsi menyiapkan tenaga-tenaga terdidik untuk guru-guru yang menjadi salah satu sumber rujukan khazanah intelektual Islam bagi pendidikan. Sejak tahun 70-an pesantren telah memberikan andil dalam melakukan pendidikan bangsa, terutama pada penyelenggaraan pendidikan formal dengan memasukkan kurikulum nasional dan pesantren menjadi salah satu sub sistem pendidikan nasional.

Depag RI (2001, hlm. 70) dalam Engku \& Zubaidah (2014: 176-177) menyajikan bukti bahwa dalam kehidupan sosial keagamaan masyarakat Indonesia dan termasuk kehidupan politik, pondok pesantren memiliki peranan yang sangat penting dalam mengembangkan kehidupan di wilayah Indonesia. Bentuk perananperanan itu antara lain: Pertama, peranan instrumental yakni dalam tataran inilah peranan pondok pesantren sebagai alat pendidikan nasional tampak sangat 
partisipatif. Kedua, peranan keagamaan yakni dalam pelaksanaannya, pondok pesantren melaksanakan proses pembinaan pengetahuan, sikap dan kecakapan yang menyangkut segi keagamaan.

Adapun Dian Nafi dkk (2007: 11) menyimpulkan bahwa pesantren mengemban beberapa peran, utamanya sebagai lembaga pendidikan Islam yang sekaligus juga memainkan peran sebagai lembaga bimbingan keagamaan, keilmuan, pelatihan, pengembangan masyarakat, dan sekaligus menjadi simpul budaya, maka itulah pondok pesantren, biasanya peranperan itu tidak langsung terbentuk, melainkan melewati tahap demi tahap. Setelah sukses sebagai lembaga pendidikan pesantren bisa pula menjadi lembaga keilmuan, kepelatihan, dan pemberdayaan masyarakat. Keberhasilan membangun integrasi dengan masyarakat barulah memberinya mandat sebagai lembaga bimbingan keagamaan simpul budaya.

Hasyim (2015) menyajikan bukti bahwa sejak dulu pesantren dikenal sebagai tempat pengkaderan ulama, tempat pengajaran ilmu agama dan memelihara tradisi Islam. Fungsi ini terus berkembang akibat tuntutan pembangunan nasional yang mengharuskan pesantren terlibat di dalamnya. Sekarang pertumbuhan pesantren sangat pesat, menjamurnya pesantren dengan spesialisasi dan ragam kajian dari tradisional hingga modern membawa dampak positif bagi pendidikan nasional secara umum dan pendidikan Islam khususnya. Kehadiran pesantren bukan hanya membantu pemerintah dalam rangka mencerdaskan bangsa yang tidak mungkin terjamah secara keseluruhan, namun lebih dari itu pesantren menawarkan jenis pendidikan alternatif bagi pengembangan pendidikan nasional.

Pondok pesantren berperan dalam membentuk lulusan yang memiliki kepribadian amar ma'ruf nahi munkar di tengah-tengah masyarakat, karena amar ma'ruf nabi munkar merupakan bentuk aktualisasi ajaran Islam. Suryana dkk (2006:
205) mencatat bahwa amar ma'ruf nahi munkar merupakan bentuk aktualisasi ajaran Islam di tengah masyarakat dengan cara menegakkan kebenaran dan membenci keburukan dan kemungkaran yang ada di tengah masyarakat. Amar ma'ruf adalah keberpihakan seorang muslim terhadap kebenaran, kendatipun kebenaran itu merugikan dirinya. Demikian pula nahi munkar atau membenci kemunkaran harus selalu ditampilkan kendatipun keburukan itu akan menguntungkan dirinya.

Sementara itu, pada saat masa penjajahan, peran pesantren di samping sebagai lembaga pendidikan Islam dan dakwah, juga telah berperan sebagai tempat yang menjadi basis perlawanan terhadap kaum kafir penjajah. Kita ambil contoh salah satu pahlawan nasional yang berasal dari Tasikmalaya yaitu Asy-Syahid K.H. Zainal Musthafa yang memberontak kepada balatentara Jepang yang dilandasi dengan Islam. Suryanegara (2014: 92) mengobservasi umumnya dalam penulisan sejarah Indonesia, akibat adanya deislamisasi dalam penulisannya, hanya dituliskan K.H. Zainal Musthafa dan Kiai Emas memberontak melawan balatentara Jepang yang menindas para petani Sukamanah Tasikmalaya. Namun, tidak dituliskan gerakan protes sosialnya menuntut Indonesia merdeka berdasarkan Islam.

Berdasarkan uraian di atas, pesantren telah lama menjadi lembaga yang memiliki kontribusi penting dalam ikut serta mencerdaskan bangsa. Banyaknya jumlah pesantren di Indonesia serta besarnya jumlah santri pada tiap pesantren menjadikan lembaga ini layak diperhitungkan dalam kaitannya dengan pembangunan bangsa di bidang pendidikan dan moral (Syarifah, 2016). Dalam perkembangannya, peran pondok pesantren sebagai lembaga pendidikan di Indonesia tentunya masih memiliki beberapa kekurangan. Engku \& Zubaidah (2014: 181182) mengamati bahwa salah satu kekurangan dunia pesantren hingga dewasa 
ini adalah kurangnya pengembangan pemikiran analitis dalam tradisi membaca teks kitab kuning. Oleh karena itu, diperlukan upaya-upaya cerdas merumuskan kembali kurikulum pendidikan dalam sebuah sistem pendidikan terpadu dan menyeluruh. Dengan demikian, peluang terbentuknya intelektual muslim yang memiliki kepekaan spiritual lebih bisa dimungkinkan lahir dari kalangan pesantren. Adapun Aly (2011: 7-8) mencatat bahwa dalam dunia pesantren perlu adanya pengembangan wawasan berpikir dengan memperkaya basis metodologi keilmuan.

Choiri \& Fitrian

(2011)

mengobservasi kini sebagian pesantren lebih terbuka untuk menerima arus modernisasi. Indikasi ini nampak dari adanya berbagai kegiatan yang mendorong partisipasi pesantren dalam pembangunan. Namun demikian, pesantren dan lembaga pendidikan Islam pada umumnya perlu melakukan telaah secara kritis agar hasil pengembangan ilmu pengetahuan dan teknologi dapat dimanfaatkan untuk kemaslahatan yang lebih besar bagi kehidupan manusia. Bukan sebaliknya, pengembangan ilmu pengetahuan dan teknologi membawa malapetaka bagi eksistensi kehidupan manusia, karena hegemoni cara berfikir kapitalis dan liberalis yang bebas nilai.

Semakin berkembangnya lembaga pendidikan modern dan semakin gencarnya pemikiran Barat (sekulerisme, pluralisme, liberalisme, dll), aliran ideologi (kapitalisme dan sosialisme/komunisme), dan gerakan modern yang mulai memasuki dunia Islam yang merupakan ancaman bagi keberlangsungan pendidikan pesantren, tetapi sistem pendidikan pesantren mampu bertahan dalam menghadapi arus pemikiran, aliran dan gerakan modern. Adapun Nasution (2013: 3) menyimpulkan bahwa maksud modernisme mengandung arti pikiran, aliran, gerakan dan usaha untuk mengubah paham-paham, adat istiadat, institusi-institusi lama, dan sebagainya untuk disesuaikan dengan suasana baru yang ditimbulkan oleh kemajuan ilmu pengetahuan dan teknologi modern. Modernisme mulai memasuki dunia Islam, terutama sesudah masuk abad 19 M, yang dalam sejarah Islam dipandang sebagai permulaian periode modern.

Dari uraian di atas, dapat disimpulkan bahwa peran pondok pesantren bukan hanya sebagai lembaga keagamaan tetapi berperan juga sebagai lembaga pendidikan, keilmuan, pelatihan, pengembangan masyarakat, basis perlawanan terhadap penjajah dan sekaligus menjadi simpul budaya. Beberapa pesantren di Indonesia telah mengalami pembaruan, tetapi ada ciri khas tradisi pesantren dalam menghadapi pembaruan tersebut. Kalangan pesantren masih mempertahankan tradisi lama yang masih baik, tetapi tidak menutup untuk mengambil hal yang baru jika itu dianggap baik. Meskipun modernisme melanda dunia Islam, salah satunya yang terjadi di Indonesia, tetapi ada dari beberapa pesantren yang masih mempertahankan sistem pendidikan tradisional. tidak terbawa arus modernisme yang gencar dibawa oleh orang-orang Barat.

\section{KESIMPULAN}

Pondok pesantren ditinjau dari segi bahasa, kata pondok berasal dari bahasa Arab funduq yang artinya hotel. Dalam perspektif masyarakat Indonesia diartikan sebagai tempat berlangsungya suatu pendidikan Agama Islam yang telah melembaga sejak zaman dahulu. Jadi, pada hakikatnya pondok pesantren merupakan lembaga pendidikan Islam yang memberikan pengajaran, pendidikan, pembinaan dan menyebarkan agama Islam. Metode utama sistem pengajarannya adalah sistem bandongan atau weton dan sorogan.

Unsur-unsur pondok pesantren terdiri dari kiai sebagai tokoh sentral, santri, masjid, kitab kuning dan asrama. Adapun klasifikasi pondok pesantren terdiri dari pesantren salafi dan pesantren khalafi. Untuk santri sendiri ada yang dikenal santri 
mukim dan santri kalong. Tujuan pendidikan pesantren adalah dalam rangka membina kepribadian Islami, yaitu kepribadian yang beriman dan bertakwa kepada Allah Subhānahu Wa Ta'ālâ, berakhlak mulia, bermanfaat dan berkhidmat kepada masyarakat dengan menjadi pelayan umat (khadim al-ummah) dalam rangka meninggikan kalimat Allah dan kejayaan kaum muslimin.

Peran pondok pesantren di Indonesia bukan hanya sebagai lembaga pendidikan tetapi berperan juga sebagai lembaga keagamaan yang menjadi basis perlawanan terhadap segala bentuk penjajahan, lembaga keilmuan, lembaga penelitian, lembaga pelatihan, dan lembaga pengembangan masyarakat sekaligus menjadi simpul budaya.

\section{DAFTAR PUSTAKA}

Abubakar, I. (2018). Strengthening Core Values Pesantren as a Local Wisdom of Islamic Higher Education Through Ma'had Jami' ah. IOP Conference Series: Earth and Environmental Science, 1-7.

Alhamuddin. (2005). Pendidikan Islam Modern ala Trimurti Pondok Modern Darussalam Gontor. AtTa'dib, 3(2), 203-231.

Aly, A. (2011). Pendidikan Islam Multikultural Di Pesantren. Yogyakarta: Pustaka Pelajar.

Bempah, R. T. (2018). Tawuran Saat Sahur, Belasan Pemuda di Bogor Ditangkap. Retrieved August 1, 2018, from https://regional.kompas.com/read/ 2018/06/04/18302691/tawuransaat-sahur-belasan-pemuda-dibogor-ditangkap

Choiri, M. M., \& Fitriani, A. (2011). Problematika Pendidikan Islam sebagai Sub Sistem Pendidikan Nasional di Era Global. Al-Tabir, 11(2), 303-325.

Dhofier, Z. (1994). Tradisi Pesantren.
Yogyakarta: LP3ES.

Dian Nafi dkk. (2007). Praksis Pembelajaran Pesantren. Yogyakarta: LKis Pelangi Aksara. Yogyakarta: LKis Pelangi Aksara.

Djumransjah, H. M. (2001). Pendidikan Pesantren dan Kemandirian Santri. Jurnal Ilmu Pendidikan, 8(2), 139-149.

Engku, I., \& Zubaidah, S. (2014). Sejarah Pendidikan Islami. Bandung: Remaja Rosdakarya.

Fauziyah, E. (2014). Pembentukan Kepribadian Santri Dalam Sistem Pondok Pesantren Salafi Miftabul Huda Cibideung Bogor (skripsi). Jakarta: Universitas Islam Negeri (UIN) Syarif Hidayatullah.

Harlina, S. (2017). 30 Remaja di Kendari Konsumsi Obat Terlarang, 1 Orang Tewas. Retrieved August 1, 2018, from

https://news.detik.com/berita/d3642097/30-remaja-di-kendarikonsumsi-obat-terlarang-1-orangtewas

Haryanto, R. (2017). Pemberdayaan Santri Podok Pesantren Musthafawiyah di Era Globalisasi (Studi Kasus Pondok Pesantren Musthafawiyah). Al-Ishlah: Jurnal Pendidikan, 9 (2), 16-32.

Hasyim, H. (2015). Transformasi Pendidikan Islam (Konteks Pendidikan Pondok Pesantren). Jurnal Pendidikan Agama Islam -Ta'lim, 13(1), 57-77.

Hasyimi, M. A. (1988). Apakah Anda Berkepribadian Muslim. Jakarta: Gema Insani.

Hidayat, T., Rizal, A. S., \& Fahrudin. (2018). Pola Pendidikan Islam di Pondok Pesantren Mahasiswa Miftahul Khoir Bandung Dalam Membentuk Kepribadian Islami. Ta'dib: Jurnal Pendidikan Islam, VII(1), 9-19.

In'ami, M. (2011). Kultur Pesantren Modern : Integrasi Sistem Madrasah dan Pesantren di Pondok Modern Gontor. Ibda': Jurnal Kebudayaan 
Islam, 9(2), 194-213.

Indonesia, P. R. (2013). Undang-Undang Republik Indonesia Nomor 20 Tahun 2003 Tentang Sistem Pendidikan Nasional. Undang-Undang Republik Indonesia, https://doi.org/10.1017/CBO9781 107415324.004

Irham. (2015). Pesantren dan Perkembangan Politik Pendidikan Agama di Indonesia. Jurnal Pendidikan Agama Islam - Ta'lim, 13(1), 93-118.

Jaafar, N., Tamuri, A. H., Muhamad, N. A. F., Ghazali, N. M., Amat, R. A. M. @, Raus, N. M., \& Hassan, S. N. S. (2012). The Importance of SelfEfficacy: A Need for Islamic Teachers as Murabbi. Procedia - Social and Behavioral Sciences, 69, 359-366. https://doi.org/10.1016/j.sbspro.20 12.11.421

Muhadjir Effendi, D. (2002). Dinamika Pemikiran Islam di Perguruan Tinggi. Jakarta: Logos Wacana Ilmu dan Pemikiran.

Nashir, R. (2010). Mencari Tipologi Format Pendidikan Ideal Pondok Pesantren di Tengah Arus Perubahan. Yogyakarta: Pustaka Pelajar.

Nasution, H. (2013). Pembaharuan Dalam Islam Sejarah Pemikiran dan Gerakan Islam. Jakarta: Bulan Bintang.

Priyantono, H. (2016). Dua Remaja Meregang Nyawa Diduga Konsumsi Miras Oplosan. Retrieved August 1, 2018, from https://daerah.sindonews.com/read /1152958/22/dua-remajameregang-nyawa-diduga-konsumsimiras-oplosan$1478306021 \% 0 \mathrm{~A} \% 0 \mathrm{~A}$

Rahardjo dkk, D. (1974). Pesantren dan Pembaharuan. Jakarta: LP3ES.

Remaja Berhubungan Seks Luar Nikah kok tak Dirisaukan? (2018). Retrieved August 1, 2018, from https://www.jpnn.com/news/rema ja-berhubungan-seks-luar-nikah- kok-tak-dirisaukan?page $=1$

Ridhwan, Nurdin, A., \& Samad, S. A. A.

(2018). Dynamics of Islamic

Education in The Land of Bugis :

Growth, Development and

Typology Pesantren in Bone. IOP

Conference Series: Earth and

Environmental Science, 1-8.

Rizal, A. S. (2011). Transformasi Corak Edukasi Dalam Sistem Pendidikan Pesantren, Dari Pola Tradisi Ke Pola Modern. Jurnal Pendidikan Agama Islam - Ta'lim, 9 (2), 95-112.

Rizal, A. S. (2012). Pendidikan Nilai Secara Active-Learning Dalam Tradisi Pondok Pesantren. Jurnal Pendidikan Agama Islam - Ta'lim, 10 (1), 1-12.

Rudi Ahmad Suryadi. (2012). Motivasi Belajar Persfektif Pendidikan Islam Klasik. Jurnal Pendidikan Agama Islam - Ta'lim, 10(1), 53-65.

Sanusi, U. (2012). Pendidikan Kemandirian di Pondok Pesantren. Jurnal Pendidikan Agama Islam, 10(2), 123139.

Sanusi, U. (2013). Transfer Ilmu Di Pesantren: Kajian Mengenai Sanad Ilmu. Jurnal Pendidikan Agama Islam, 11(1), 61-70.

Setiawan, E. (2012). Eksistensi Budaya

Patron Klien Dalam Pesantren: Studi Hubungan Antara Kiai dan Santri, 13(2), 137-152.

Sudarsih, E. (2010). Mengembangkan Wirausaha di Pondok Pesantren. Jurnal Sosial Humaniorah, 3(1), 70-77.

Suryana dkk, T. (2006). Pendidikan Agama Islam. Bandung: Tiga Mutiara.

Suryanegara, A. M. (2014). Api Sejarah 2. Bandung: Salamadani.

Syahidin. (2009). Menelusuri Metode Pendidikan Dalam al-Quran. Bandung: Alfabeta.

Syarifah. (2016). Manajemen Kurikulum Kulliyatul Mu'allimin Al-Islamiyyah di Pondok Modern Darussalam Gontor. Jurnal At-Ta'dib, 11(1), 5371.

Tamin AR, Z. (2015). Pesantren dan Politik 
(Siergi Pendidikan Pesantren dan Kepemimpinan dalam Pandangan

KH. M. Hasyim Asy'ari). Jurnal

Pendidikan Agama Islam, 3(2), 324345.

Tuanaya dkk, A. M. M. T. T. (2007).

Modernisasi Pesantren. Jakarta: Balai

Penelitian dan Pengembangan

Agama.

Yahya, I. D. (2006). Ajengan Cipasung Biografi

KH. Moh. Ilyas Ruchiat. Yogyakarta:

Pustaka Pesantren. 